\title{
The Participation of Firms in Tax Incentive Programs
}

\author{
Dagney Faulk*
}

\begin{abstract}
This paper analyzes firms that are eligible to participate in Georgia's Job Tax Credit program to determine the characteristics that influence the probability of filing for a state employment tax credit. Empirical results indicate that firms with higher state corporate income tax liability, previous participation, a larger number of jobs credited, and headquartered in the state are more likely to participate in the tax credit program. Larger firms and start-ups are less likely to participate in the tax credit program.
\end{abstract}

\section{INTRODUCTION}

In the United States and other countries, tax incentives have been widely utilized by governments to encourage firms to expand employment. Many of these incentives are in the form of corporate income tax credits, such as employment tax credits, investment tax credits, and job training tax credits, which are available to a broad group of firms that meet certain eligibility criteria. ${ }^{1}$ Over the past two decades, state governments in the United States, engaging in tax competition, have expanded the number of available tax credits. This paper focuses specifically on employment tax credits, which are among the most utilized, with over half of the states in the U.S. offering this type of tax credit.

Previous research on federal and state employment tax credit programs suggests that participation rates are extremely low. Faulk (1998) finds that 19 percent of eligible firms participate in Georgia's Job Tax Credit (JTC) program. Bishop and Montgomery (1986) estimate that less than 3 percent of eligible firms participate in federal employment tax credit programs in the United States and that lack of knowledge about these programs and firm size are the most important determinants of response rates. Gabe and Kraybill (1998) investigate the probability of a business receiving Ohio's Job Creation Tax Credit and find that the number of jobs promised and the size of the labor force in the project area increase the probability of receiving the credit, and that a past decrease in the business' employment growth rate also increases the probability of receiving the credit. ${ }^{2}$ This paper develops a conceptual framework of the firm's participation decision and uses a logit model to predict a firm's probability of participating in a state's employment tax credit program. Data from firms eligible to take Georgia's JTC are used in the

*Assistant Professor of Economics, Indiana University Southeast, New Albany, IN. The Georgia Department of Labor and the Georgia Department of Revenue were instrumental in obtaining the data used in this study. I thank anonymous referees for their comments.

1For example, firms have to create some minimum number of jobs, make a certain level of investment, or be in a specific industry.

2Ohio's Job Creation Tax credit is not generally available to a broad group of corporations. The credit is project based, and corporations must apply for it and receive the credit only if approved by the state. 
analysis. The analysis addresses the question: what are the characteristics that influence participation in tax credit programs? The conceptual and empirical frameworks provide insight into the firm's participation decision.

The purpose of this paper is not to evaluate the effectiveness of the tax incentive in creating jobs or encouraging start-ups. Bartik (1991) and Wasylenko (1997) evaluate studies that focus on this issue. Loveridge (1996) examines arguments for and against industrial recruitment as an economic development strategy. This study, instead, examines the factors that influence a firm's participation in tax incentive programs, which are available to broad groups of businesses in a state. A better understanding of the characteristics of firms that participate in tax incentive programs and the factors that affect participation should help policy makers design incentives that are more effective policy tools. The analysis suggests that firm size, previous participation, headquarters location, and the number of jobs creditable are dominant influences on the firm's participation decision.

The remainder of the paper is organized as follows: the next section provides a conceptual framework for analyzing the firm's participation decision. The following section presents the empirical specification. The fourth section provides a brief overview of the structure of Georgia's JTC program. The fifth section discusses the data and variables used in the analysis. The sixth section discusses the model results. The final section offers conclusions.

\section{CONCEPTUAL FRAMEWORK}

TABLE 1

Costs of Participating in Tax Credit Programs

\begin{tabular}{ll}
\hline Costs & Description \\
\hline Search & Costs associated with finding out about the credit.
\end{tabular}

Compliance

Start-up costs: learning about the credit, training staff, setting up new forms and systems to capture information.

Annual costs: year-to-year costs of claiming the credit. Internal coordination costs: personnel in charge of hiring decisions need to share information with personnel in charge of taxes.

Providing additional information to government

Stigma

Hiring

Additional federal tax liability
Increased probability of audit.

Public scrutiny, belief that tax credits are a form of corporate welfare.

Interviewing and training of workers. If labor turnover is high, the firm must replace workers to remain eligible for the credit.

State corporate income tax liability is deductible from federal corporate income tax liability. 
The traditional cost/benefit framework is used to formalize the firm's decision to participate in an employment tax credit program. The firm's objective is to maximize profit. The incremental change in profit resulting from the credit depends on the cost and benefits of taking the credit. The benefit of participation in a tax credit program is the reduction in corporate income tax liability that is attributable to the tax credit. The benefit of participation is determined by the credit structure and firm characteristics, particularly the number of jobs created, current tax liability, the tax credit ceiling, and the discount rate associated with future credits and any carryforward. The costs of participation can be divided into six categories: (1) search costs; (2) compliance costs; (3) costs associated with providing additional information to the government; (4) stigma costs; (5) hiring costs; and (6) additional federal tax liability. These costs are detailed in Table 1. While the costs and benefits of participation are not specifically measurable, they can be linked to firm characteristics.

\section{EMPIRICAL SPECIFICATION}

The underlying model suggests that firms will participate in a tax credit program if the benefits of participation are greater than the costs. The costs and benefits of participation are not directly observable. The observed outcome is whether the firm participates in the program or not.

The variable $Z_{i}^{*}$ is an unobserved variable that indicates the incremental change in profit resulting from participation in the tax credit program. A firm will participate if $Z_{i}^{*}$ is positive (benefits are greater costs). Rather than $Z_{i}^{*}$, one observes $Z_{i}$, whether the firm participates or not.

$$
Z_{i}=\left\{\begin{array}{c}
1 \text { if } Z_{i}^{*}>0 \\
0 \text { otherwise }
\end{array} .\right.
$$

As suggested by the model, $\mathrm{Z}_{\mathrm{i}}$ is related to a set of firm characteristics.

The logit specification estimates the probability that the firm participates given the firm's characteristics:

$$
P\left(Z_{i}=1\right)=\frac{e^{\beta^{\prime} x_{i}}}{1+e^{\beta^{\prime} x_{i}}}
$$

where $P=$ the firm's probability of participating;

$\mathrm{Z}_{\mathrm{i}}=$ indicator variable that equals 1 if the firm participates in the tax credit program, 0 otherwise; and

$X_{i}=a$ vector of firm characteristics.

The logit model was chosen (over the probit model) because of the mathematical convenience of computing specific marginal effects. 


\section{PROGRAM DESCRIPTION}

The structure of the employment tax credit program influences the costs and benefits of participation. Some relevant economic features of Georgia's JTC include the following:

1. Georgia's JTC is a tax credit available for the creation of new full-time jobs.

2. The JTC is a credit against corporate income tax liability.

3. Fifty percent of a firm's income tax liability is the maximum JTC a firm can take in any year.

4. If the minimum number of jobs is not maintained, the firm does not have to refund a portion of the previous year's credit back to the state.

5. The minimum number of new jobs that a business establishment must create to qualify for the JTC and the credit per job differs depending on the Tier designation of the county in which the establishment is located (Table 2). ${ }^{3}$ Establishments located in Tier 1 counties have to create fewer jobs to qualify for the JTC, and the credit per job is higher relative to the other tiers. Through this mechanism, the JTC targets business establishments in less-developed counties.

\section{TABLE 2}

Georgia's Job Tax Credit Eligibility Requirements, Minimum Job Creation Criteria, and Credit Amounts Per Job Created

\begin{tabular}{|c|c|c|c|c|c|c|}
\hline Tax Year & \multicolumn{2}{|c|}{ Tier 1 Counties } & \multicolumn{2}{|c|}{ Tier 2 Counties } & \multicolumn{2}{|c|}{ Tier 3 Counties } \\
\hline$\overline{1991}$ & $\begin{array}{l}\text { Jobs: } \\
\text { Credit: }\end{array}$ & $\begin{array}{l}10 \\
\$ 1,000\end{array}$ & \multicolumn{2}{|c|}{ Not Eligible } & \multicolumn{2}{|c|}{ Not Eligible } \\
\hline 1992 & $\begin{array}{l}\text { Jobs: } \\
\text { Credit: }\end{array}$ & $\begin{array}{l}10 \\
\$ 1,000\end{array}$ & \multicolumn{2}{|c|}{ Not Eligible } & \multicolumn{2}{|c|}{ Not Eligible } \\
\hline 1993 & $\begin{array}{l}\text { Jobs: } \\
\text { Credit: }\end{array}$ & $\begin{array}{l}10 \\
\$ 2,000\end{array}$ & $\begin{array}{l}\text { Jobs: } \\
\text { Credit: }\end{array}$ & $\begin{array}{l}10 \\
\$ 1,000\end{array}$ & \multicolumn{2}{|c|}{ Not Eligible } \\
\hline 1994 & $\begin{array}{l}\text { Jobs: } \\
\text { Credit: }\end{array}$ & $\begin{array}{l}10 \\
\$ 2,000\end{array}$ & $\begin{array}{l}\text { Jobs: } \\
\text { Credit: }\end{array}$ & $\begin{array}{l}10 \\
\$ 1,000\end{array}$ & \multicolumn{2}{|c|}{ Not Eligible } \\
\hline 1995 & $\begin{array}{l}\text { Jobs: } \\
\text { Credit: }\end{array}$ & $\begin{array}{l}10 \\
\$ 2,500\end{array}$ & $\begin{array}{l}\text { Jobs: } \\
\text { Credit: }\end{array}$ & $\begin{array}{l}25 \\
\$ 1,500\end{array}$ & $\begin{array}{l}\text { Jobs: } \\
\text { Credit: }\end{array}$ & $\begin{array}{l}50 \\
\$ 500\end{array}$ \\
\hline 1996 & $\begin{array}{l}\text { Jobs: } \\
\text { Credit: }\end{array}$ & $\begin{array}{l}5 \\
\$ 2,500\end{array}$ & $\begin{array}{l}\text { Jobs: } \\
\text { Credit: }\end{array}$ & $\begin{array}{l}25 \\
\$ 1,500\end{array}$ & $\begin{array}{l}\text { Jobs: } \\
\text { Credit: }\end{array}$ & $\begin{array}{l}50 \\
\$ 500\end{array}$ \\
\hline 1997 & $\begin{array}{l}\text { Jobs: } \\
\text { Credit: }\end{array}$ & $\begin{array}{l}5 \\
\$ 2,500\end{array}$ & $\begin{array}{l}\text { Jobs: } \\
\text { Credit: }\end{array}$ & $\begin{array}{l}15 \\
\$ 1,500\end{array}$ & $\begin{array}{l}\text { Jobs: } \\
\text { Credit: }\end{array}$ & $\begin{array}{l}25 \\
\$ 500\end{array}$ \\
\hline
\end{tabular}

${ }^{3}$ Each year the Department of Community Affairs ranks the level of economic development in each of Georgia's 159 counties and assigns each county to one of three tiers. A county's level of economic development is determined by its unemployment rate, average manufacturing wage, poverty rate, and per capita income. Tier 1 counties are the least developed, while Tier 3 counties are the most developed. 
6. An establishment must maintain a minimum increase of jobs for two full years before it can take the JTC. A firm's increase in employment is determined by the increase in the average monthly employment over the firm's fiscal year. The firm supplies this information on the tax credit schedule when claiming the credit.

7. The JTC can be taken for five years if the jobs are maintained. Unused credit can be carried forward for up to ten years. For example, if a firm in an eligible industry in a Tier 1 county chose 1992 as the base year, created ten new full-time jobs in 1993 and maintained them in 1994, it can claim a JTC of $\$ 20,000$ on its 1994 tax return as long as the firm has a state corporate income tax liability of at least $\$ 40,000$. If the establishment maintains these ten jobs, it can continue to take the JTC through the 1998 tax year. The firm must maintain the minimum employment increase for seven years in order to take the credit for five years. The above provisions reduce the incentive for churning, i.e., where establishments hire workers, fire them, and then hire new workers to take advantage of the credit continuously.

8. With the exception of firms in Tier 1 counties, the JTC is limited to certain industries, currently manufacturing and distribution, warehousing, goods processing, tourism, research and development, and information processing. In Tier 1 counties, firms in any industry can take the JTC.

9. The JTC is nonrefundable, but unused JTC can be carried forward for up to ten years.

10.Firms can file a Notice of Intent to maintain Tier status. For example, a firm would file a Notice of Intent for a participating establishment located in a Tier 1 county so that if the county is classified as Tier 2 the following year, the firm can continue to claim the Tier 1 credit amount. From 1993 to 1995, 29 establishments filed a Notice of Intent for the JTC in Georgia.

11. The JTC does not require firms to sign an a priori contract guaranteeing the creation of a set number of jobs. Firms can track employment and decide to claim the JTC after the legislated number of jobs is created.

12.Multi-establishment firms in qualifying industries may take the JTC for jobs created in any single establishment that meets the job creation criteria. Internal coordination costs may be substantial for this type of firm.

\section{DATA AND EXPLANATORY VARIABLES}

The data used to estimate the model are from corporate income tax returns of firms that were eligible to take Georgia's JTC between 1993 and 1995 and the Georgia Department of Labor's ES202 data. ${ }^{4}$ The ES202 data were used to identify a sample of firms that were eligible to take the JTC and did not. The sample consists of 151 firms eligible to take the JTC; 70 took the credit and 81 did not. Table

${ }^{4}$ The Georgia Department of Labor's ES202 data set contains information on monthly employment levels, industry, unemployment tax payments, total wage bill, and county for each business establishment in Georgia. 
3 provides the definitions and sources for variables used in the model. Descriptive statistics are shown in Table 4.

\section{TABLE 3}

Description of Variables Used in the Participation Equation

\begin{tabular}{ll}
\hline Variable & Description \\
\hline Participation Dummy & $\begin{array}{l}=1 \text { if firm took the JTC (had a positive JTC) } \\
=0 \text { if firm did not take the JTC or claimed } \\
\text { zero JTC }\end{array}$ \\
Tax Liability & $\begin{array}{l}\text { Pre-JTC tax liability on the Georgia } \\
\text { Corporate Income Tax return (in 10,000s) }\end{array}$ \\
Rank & $\begin{array}{l}\text { Each of Georgia's } 159 \text { counties is assigned } \\
\text { a rank based on the average manufacturing } \\
\text { wage, poverty rate, unemployment rate and } \\
\text { per capita income. } 1 \text { is the lowest rank. } \\
\text { 159 is the highest rank. }\end{array}$
\end{tabular}

Initial Employment

The number of employees in the base year

Previous JTC

Jobs Credited

Headquarters Location

Manufacturing Dummy

Start-Up

Rank*Year 95

Age

Age $^{2}$
$=1$ if firms took JTC previously

$=0$ otherwise

Number of jobs credited in a tax year

$=1$ if firm's headquarters is in Georgia

$=0$ otherwise

$=1$ for manufacturing firms

$=1$ if the base year employment was zero $=0$ otherwise

Interaction of the rank of the county

where firm is located and a year dummy

Age of the firm measured as the income tax year less the year of incorporation in GA
$=0$ otherwise

Source

Georgia Corporate Income Tax Returns and ES202 data

Georgia Corporate Income Tax Returns

Georgia Corporate Income Tax Returns or ES202 data

Georgia Corporate Income Tax Returns or ES202 data

Georgia Corporate Income Tax Returns

Georgia Corporate Income Tax Returns

Georgia Corporate Income Tax Returns

Georgia Corporate Income Tax Returns or ES202 data

Georgia Corporate Income Tax Returns or ES202 data

Georgia Corporate Income Tax Returns

The dependent variable is a dummy variable indicating whether or not the firm participated in the program between 1993 and 1995.

The level of tax liability determines, in part, the benefit to the firm of participating in an employment tax credit program. Firms that consistently have low or no state tax liability have little incentive to take the JTC, while firms with high 
state tax liabilities in the current year are more likely to look for ways to decrease this liability and are more likely to take the JTC. ${ }^{5}$

Firms located in the less-developed counties (counties with a lower rank) may be more likely to take the credit since the credit per job created is higher for these counties and the job creation threshold is lower. For firms with similar attributes and costs associated with taking the credit, the benefit from taking the credit is higher in counties with a lower rank. It is hypothesized that firms located in counties with a lower rank are most likely to participate.

Initial employment is a measure of firm size. Is providing a tax incentive to a large firm a better use of resources than providing the same incentive to a small firm? Policy makers are interested in the effect of tax incentives on firms of different sizes.

Firms that have previously taken the JTC are probably more likely to take the credit in the present tax year. These firms know about the JTC and have incurred the fixed cost of gathering information and filling out the forms. If a firm has no tax liability, however, the firm that took the JTC previously may not take the JTC in the current year, especially if it expects to have no tax liability in the future, or if the firm believes that taking the credit will increase the probability of audit.

As the number of jobs for which the firm is eligible to claim the JTC increases, the firm should be more likely to claim the JTC. The marginal participation cost associated with an additional job is probably quite low, so that firms can take advantage of a type of scale economy as the number of jobs credited increases. However, if the number of creditable jobs times the credit amount for which the firm is eligible given its location is greater than half of the firm's corporate tax liability, the effective credit rate is lower than the statutory credit rate, which may reduce the firm's likelihood of taking the credit.

It is hypothesized that a firm headquartered in the state is more likely to take the JTC. It has greater access to information about tax advantages, therefore it may be less costly to obtain information about tax abatement in the state where the firm is headquartered.

Firms in particular industries may be more likely to take the credit either because certain industries use more labor, can more easily increase employment, or are more likely to have high tax liabilities. Since firms in the manufacturing industry use more labor relative to other qualifying industries, these firms may be more likely to take the JTC.

Start-ups include new firms and existing firms that open new plants. Startups may be more likely to take the JTC since they are able to claim a credit for their entire payroll. Start-up firms typically have low tax liability for the first several years of operation, which may reduce the likelihood of taking the credit.

${ }^{5}$ According to Georgia Department of Revenue annual reports, just over 75 percent of corporations in the state have no state corporate income tax liability in any given year. 
In 1995, Tier 3 firms became eligible to take the JTC. The rank/year interaction variable was included in the model to control for this change in the credit structure.

Young firms often operate "in the red" and therefore have no corporate income tax liability and are less likely to participate in tax credit programs. Age ${ }^{2}$ controls for the expected nonlinear relationship of this variable with participation. The probability of participating is expected to increase with age but at a decreasing rate.

TABLE 4

Summary Statistics of Variables Used in the Participation Equation

\begin{tabular}{lcccc}
\hline Variable & Mean & $\begin{array}{c}\text { Standard } \\
\text { Deviation }\end{array}$ & $\begin{array}{c}\text { Minimum } \\
\text { (Counts for Dummy Variables) }\end{array}$ \\
\hline Participation Dummy & 0.4635 & 0.5003 & $0(81)$ & $1(70)$ \\
Tax Liability $(\$ 10,000)$ & 30.2178 & 82.2216 & 0 & 517.41 \\
Rank & 61.6500 & 43.6547 & 1 & 159 \\
Initial Employment & 300.9271 & 558.2 & 0 & 4,540 \\
Previous JTC & 0.3046 & 0.4617 & $0(105)$ & $1(46)$ \\
Jobs Credited & 52.6556 & 102.3155 & 0 & 834 \\
Headquarters Location & 0.5695 & 0.4967 & $0(65)$ & $1(86)$ \\
Start-Up & 0.2582 & 0.4391 & $0(112)$ & $1(39)$ \\
Manufacturing Dummy & 0.8940 & 0.3088 & $0(16)$ & $1(135)$ \\
Rank*Year 95 & 46.2875 & 51.5242 & 0 & 159 \\
Age & 19.3112 & 18.2245 & 0 & 84 \\
Age & 702.8609 & $1,255.6106$ & 0 & 7,056 \\
Obs. $=151$ & & & & \\
\hline
\end{tabular}

\section{ESTIMATION RESULTS}

The use of microdata permits an examination of firm characteristics that influence the costs and benefits of participating in an employment tax credit program. The parameter estimates for the participation equation are shown in Table 5. The marginal effects, which show how the probability of taking the JTC changes when firm characteristics are altered, are described in Table 6. The typical (or average) firm is a manufacturing firm with just over $\$ 30,000$ in state corporate income tax liability, that employed 300 workers in the base year, that is headquartered in Georgia, that has not previously taken the JTC, that is 20 years old, and that is located in a Tier 2 county (see Table 4).

The model estimates show that tax liability is a significant, positive, but small, influence on the firm's likelihood of taking the JTC. As the marginal effects in Table 6 indicate, a change in the pre-credit tax liability of the average firm has a relatively small effect on a firm's probability of taking the JTC. According to these results, a $\$ 10,000$ increase in tax liability increases the probability of filing for the JTC by 0.54 percentage point. Even though employment tax credits provide a lower tax rate to participating firms, the small magnitude of the marginal effect indicates that taxes are not one of the primary considerations in the participation decision. 


\section{TABLE 5}

Logit Parameter Estimates of the Participation Model

\begin{tabular}{lccc}
\hline Variable & Parameter Estimate & Standard Error & T-ratio \\
\hline Intercept & -1.3637 & 1.5556 & 0.877 \\
Tax Liability & $0.0421^{*}$ & 0.0159 & 2.659 \\
Rank & 0.0079 & 0.0141 & 0.560 \\
Initial Employment & $-0.0052^{*}$ & 0.0017 & 2.968 \\
Previous JTC & $1.4779^{*}$ & 0.7171 & 2.061 \\
Jobs Credited & $0.0510^{*}$ & 0.0124 & 4.107 \\
Headquarters Location & $2.4866^{*}$ & 0.7702 & 3.228 \\
Manufacturing Dummy & -1.5790 & 1.1596 & 1.362 \\
Start-Up & $-1.9660^{*}$ & 0.8463 & 2.323 \\
Rank*Year 95 & $-0.0210^{* *}$ & 0.1234 & 1.704 \\
Age & 0.0257 & 0.0532 & 0.484 \\
Age & -0.0003 & 0.0007 & 0.423 \\
Obs. $=151$ & & & \\
\hline
\end{tabular}

Goodness of Fit: The joint predictions for the model were $75 / 81$ for $J \mathrm{TCD}=0$ and $63 / 70$ for $J \mathrm{TCD}=1$. The total predictions were $82 / 81$ for JTCD $=0$ and $69 / 70$ for JTCD $=1$.

Log likelihood function $=-40.47198$

* Significant at the $95 \%$ confidence level in a two-tailed test.

**Significant at the $90 \%$ confidence level in a two-tailed test.

The rank of the county in which the firm is located is not a significant influence on a firm's likelihood of taking the JTC. Although 68 percent of participating firms are located in Tier 1 counties, firms located in less-developed counties are not more likely to participate in the JTC program when other factors are taken into account. ${ }^{6}$ Even though the credit amount per job is higher and the job creation threshold is lower in less-developed counties, perhaps they are not high/ low enough to encourage participation.

\section{TABLE 6}

Marginal Effects of Participation in the JTC Program

\begin{tabular}{lc}
\hline Variable & Effect on the Probability of Taking the JTC \\
\hline Tax Liability increases by $\$ 10,000$ & 0.54 \\
Initial Employment increases by 100 & -8.1 \\
Initial Employment decreases by 100 & 5.6 \\
Typical firm takes the JTC & 11.3 \\
The number of jobs credited increases by 10 & 5.5 \\
The number of jobs credited decreases by 10 & -7.8 \\
Typical firm is not headquartered in GA & -53.2 \\
The typical firm is a start-up & -4.1
\end{tabular}

Note: Marginal effects are calculated at mean values of the independent variables for continuous variables and at 1 if the majority of firms in the sample share the characteristic or 0 if the majority of firms do not share the characteristic for the dichotomous variables.

The model estimates show that the size of the firm is negatively related to a firm's likelihood of taking the JTC. Smaller firms are more likely to take the JTC. The marginal effects indicate that a 100 -worker increase in initial firm size decreases the probability of taking the JTC by 8.1 percentage points, while a 100worker decrease in initial firm size increases the probability of taking the credit by 5.6 percentage points. The result that smaller firms are more likely to participate may be explained in part by the relative costs of participating for firms of different

${ }^{6}$ Of start-ups, 33 percent (13 firms) are located in Tier 1 counties. 
sizes. On the one hand, smaller firms may have fewer resources to devote to finding tax abatement. On the other hand, they may have more of an incentive to discover abatement programs since taxes may be a larger proportion of total costs. Also, smaller firms may face credit rationing or other financial constraints that make tax credits more valuable to them. In addition, larger firms experience greater difficulty coordinating information needed to claim the JTC, which increases the cost of taking the credit. In a smaller firm, the same person is more likely to be in charge of hiring and taxes, so coordination costs are lower. Gabe and Kraybill (1998) and Pope and Kuhle (1996) also find that smaller firms are more likely to take an employment tax credit.

The model estimates show that firms that previously took the JTC are more likely to take the JTC in the current year. The marginal effects indicate that previous participation has a relatively large effect on a firm's probability of taking the credit. Since firms have already incurred the cost of finding out about the credit and developing the appropriate systems to track information necessary to claim the credit, they are expected to continue to participate.

The model estimates show that the likelihood of taking the JTC increases with the number of jobs that are creditable. The marginal effects indicate that a ten-unit increase in the number of creditable jobs increases the probability of taking the JTC by 5.5 percentage points. The number of jobs creditable is the number for which the firm can potentially take the credit before tax liability is considered. Recall that the maximum JTC is limited to half of a firm's tax liability, so the amount of the credit available to the firm is not necessarily directly related to the number of jobs that are creditable in each firm. In a similar vein, Gabe and Kraybill (1998) find that the likelihood of receiving Ohio's Job Creation Tax Credit increases with the number of new jobs that each establishment agrees to create.

The model estimates show that firms headquartered in Georgia are more likely to take the JTC. The typical firm in the sample is headquartered in Georgia. As the marginal effects indicate, a change in the headquarters location has a relatively large effect on a firm's probability of taking the credit. If the typical firm were not headquartered in the state, the probability of taking the credit would decrease by 53 percentage points. Details on how to file for the JTC and information on the credit amounts and Tier structure are not readily available in the corporate income tax forms or instructions or over the Internet. Perhaps firms headquartered in the state are more likely to have information about tax abatement through word of mouth, political connections, or tax advisors who are more familiar with Georgia tax abatements. An alternative explanation is that firms headquartered in the state are more likely to increase employment in the state, qualify for the credit, and therefore apply for it.

Being a manufacturing firm is not a significant influence on a firm's likelihood of taking the JTC. Even though 89 percent of the sample are manufacturing firms, when other variables are taken into account, this is not a significant determinant of participation. In their study of Ohio's Job Creation Tax Credit, Gabe and 
Kraybill (1998) use a larger data set and include 18 industry dummies as explanatory variables to determine if business establishments in certain industries are more likely to receive a tax credit. None of the industry variables are significant. For the Georgia and Ohio employment tax credit programs, at least, industry does not appear to be a significant influence on the likelihood of participation.

The model estimates show that start-up firms are less likely to take the JTC. One reason for this result is that start-ups have a much lower tax liability than existing firms. The average tax liability of start-ups is much lower than the tax liability of nonstart-ups, at $\$ 92,435$ and $\$ 375,212$, respectively. ${ }^{7}$ Of the start-up firms, 43.6 percent ( 17 firms) have no tax liability. Of the 22 start-ups with positive tax liability, 13 (59 percent) did not take the JTC. The typical firm in the sample is not a start-up. The marginal effects indicate that if it were, the probability of taking the JTC would decrease by 4 percentage points.

The model results show that there is a negative relationship between the interaction variable and the likelihood of taking the JTC. As the rank of the county in which the firm is located increases, the firm is less likely to take the credit in 1995. In this year, firms in counties with a higher rank (Tier 3 counties) are less likely to take the JTC relative to firms in other counties. ${ }^{8}$ Since 1995 is the first year that firms in Tier 3 counties could take the credit, many eligible firms in these counties may not have known that they were eligible. Additional years of data need to be included in the sample before we can conclude that the JTC increases employment in Tier 1 and 2 counties relative to Tier 3 counties.

The variables Age and $\mathrm{Age}^{2}$ have the expected signs but are not significant determinants of participation.

\section{CONCLUSIONS}

Few studies have focused on specific state tax incentives such as employment tax credits. This study lays out a conceptual framework, which suggests that the firm's decision to participate in tax incentives programs is derived from the costs and benefits of participation. The low participation rate in many employment tax credit programs suggests that the costs of participating are greater than the benefits. Results from the empirical model suggest that tax incentive outcomes are consistent with the model. The major results of the study are:

1.Tax liability is a positive and significant determinant of participation, but the magnitude of the marginal effect is very small, indicating that the variable does not have a substantial impact on the firm's participation decision. The credit ceiling (the maximum credit is half of tax liability) severely limits the value of the credit. Firms with low corporate income tax liability or no corporate tax liability have little incentive to take the credit.

7The tax liability of start-ups is significantly less than that of nonstart-ups at a $99 \%$ confidence level in a onetailed test.

8Tier 3 counties are those counties located in the most "developed" parts of the state, primarily metropolitan areas such as Atlanta, Savannah, and Valdosta. 
2.The job creation threshold is lower and the credit amount per job is higher in less-developed counties. Yet, eligible firms with locations in lessdeveloped parts of the state are not more likely to participate in the JTC program. This suggests that either larger credits or a different mechanism may be needed to encourage participation.

3.Manufacturing firms are not more likely to participate in the JTC program, which suggests that industry targeting is not effective.

4.Smaller firms are more likely to participate in the JTC program. However, the average employment change is substantially lower: the average employment change, among firms participating in Georgia's JTC program, is 36 in small firms versus 108 for larger firms (where smaller firms are defined as having initial employment of 100 or less). More research needs to be done to determine if it would be cost-effective for the state to target smaller firms.

5.Firms headquartered in the state are more likely to participate.

6.Start-ups are less likely to take the credit.

\section{REFERENCES}

Bartik, Timothy J. Who Benefits from State and Local Economic Development Policies? Kalamazoo, MI: W.E. Upjohn Institute, 1991.

Bishop, John H., and Mark Montgomery. "Evidence on Firm Participation in Employment Subsidy Programs." Industrial Relations 25 (1) (1986), 56-64.

Faulk, Dagney. "Georgia's Job Tax Credit: An Analysis of the Characteristics of Eligible Firms." Atlanta, GA: Georgia State University Fiscal Research Program, June 1998.

Gabe, Todd M., and David S. Kraybill. "Tax Incentives and Offers in a State Economic Development Program." The Review of Regional Studies 28 (3) (1998), $1-14$.

Loveridge, Scott. "On the Continuing Popularity of Industrial Recruitment." Economic Development Quarterly 10 (2) (1996), 151-158.

Pope, Ralph A., and James L. Kuhle. "Tax Credits for Job Creation and Job Retention in the California Economy." Public Finance Quarterly 24 (2) (1996), 192-215.

Wasylenko, Michael. "Taxation and Economic Development: The State of the Economic Literature." New England Economic Review (March/April 1997), 37-52. 